\title{
THE IMPACT OF CORPORATE SOCIAL RESPONSIBILITY FACTORS ON THE COMPETITIVENESS OF SMALL AND MEDIUM-SIZED ENTERPRISES
}

\author{
Peter Turyakira \\ Department of Marketing and Management, Makerere University, Uganda \\ EImarie Venter and Elroy Smith \\ Department of Business Management, Nelson Mandela Metropolitan University \\ Accepted: October 2013
}

\begin{abstract}
Corporate social responsibility (CSR) has become increasingly important to the competitiveness of small and medium-sized enterprises (SMEs). A positive relationship between the CSR activities of SMEs and their enhanced competitiveness exists, at least if a long-term perspective is adopted (European Competitiveness Report, 2008:106; Mandl \& Dorr, 2007:2). Despite the widespread practical and academic interest in CSR and its impact on the competitiveness of SMEs, few theoretical and empirical contributions could be found. The primary objective of this study was to identify and empirically test the CSR factors influencing the competitiveness of SMEs in Uganda. The outcomes of this study will assist SMEs to effectively and responsibly manage their activities to increase their competitiveness. A structured, self-administered questionnaire was distributed to 750 potential SME respondents. The respondents were identified by means of a purposive sampling technique, and the data were collected from 383 usable questionnaires. An exploratory factor analysis was carried out, and Cronbach's alpha coefficients calculated to determine the discriminant validity and reliability of the measuring instrument. Correlations were assessed using structural equation modeling. The empirical results of this study indicate that workforce-oriented CSR activities, society-oriented CSR activities, market-oriented CSR activities and regulated CSR activities significantly influence the competitiveness of SMEs.
\end{abstract}

Key words: CSR activities, competitiveness, SMEs

JEL: M140-443

\section{1 \\ Introduction and problem statement}

Corporate social responsibility (CSR) is viewed as a vital concept that businesses of all types and sizes need to understand and address (Charitoudi, Sariannidis \& Giannarakis, 2011: 20). As global competitiveness continues to follow momentous trends, CSR is proposed as an effective strategy for invigorating the operations and competitiveness of SMEs (Porter \& Kramer, 2006:79). CSR has become increasingly important to the competitiveness of small and medium-sized enterprises (SMEs). CSR has progressively gained acceptance and prominence both as a business tool and as a contribution to social progress (Olanrewaju, 2012:18). A positive relationship between the CSR activities of SMEs and their enhanced competitiveness exists, at least if a long-term perspective is adopted (European Competitiveness Report, 2008:106; Mandl \& Dorr, 2007:2). To remain competitive, business managers must determine how their businesses can become socially responsible, ecologically sustainable and economically competitive (Orlitzky, Siegel \& Waldman, 2011:7). Both business and society gain when a business actively strives to be socially responsible (Olanrewaju, 2012:21).

Although CSR has been discussed mainly in the context of larger enterprises, it is also a strategic tool for enhancing the competitiveness of SMEs (Szabo, 2008:17). There are 
basic CSR issues that all businesses, irrespective of their size, have to respond to, such as the creation of a good working environment where diversity is encouraged, fair distribution of wealth in a community, protection of the environment, market innovations and ethical practices (Jenkins, 2006b:2; European Competitiveness Report, 2008:119). In spite of the continual public pronouncements about their assumed importance as instruments of development, SMEs in many African countries still lack effective knowledge of modern competitiveness techniques such as CSR. Yet CSR has been identified as a potential tool for enhancing competitiveness among businesses (Filho, Wanderley, Gómez \& Farache, 2010:294).

Despite the widespread practical and academic interest in CSR and its impact on the competitiveness of SMEs, few theoretical and empirical contributions exist (European Competitiveness Report, 2008:106, Málovics, 2009:222). Quantitative and qualitative research with respect to CSR in SMEs is limited, especially in developing countries (Liu \& Fong, 2010:34). In the light of the perceived positive effects of CSR practices on SMEs, a closer examination of the relationship between CSR factors and the competitiveness of SMEs is therefore crucial. In this study, small and medium-sized enterprises are considered to be businesses that employ more than 5 but fewer than 100 persons while competitiveness refers to a business's ability to sustain its long-term performance better than its competitors in the market, as indicated by profitability, market share, sales and growth rate. The main aim of this paper is to identify and empirically test the impact of selected CSR-related factors on the competitiveness of SMEs. Based on the findings, recommendations will be made to assist SMEs to effectively manage activities inside their businesses, which could result in increased competitiveness.

2

\section{Primary objective}

The primary objective of this research is to gain insight into the use of CSR factors in SMEs and their potential impact on competitiveness.
3

\section{Secondary objectives}

To address the primary objective, the following secondary objectives have been formulated:

i To undertake a detailed theoretical investigation into the various CSR factors that could influence the performance of SMEs in Uganda.

ii To develop a hypothesised model, suggest appropriate hypotheses, and construct a path diagram of the relationships between the independent variables (CSR factors) and their influence on the competitiveness of SMEs (dependent variable).

iii To determine appropriate measuring instruments that will empirically test the relationships as described in the hypothesised model.

iv To empirically test the proposed model and to investigate the possible relationships between CSR factors and increased competitiveness.

\section{4}

\section{CSR factors that influence the competitiveness of SMEs}

CSR factors constitute the independent variables of this study. CSR has remained a broad, complex and continually evolving notion that encompasses a variety of ideas and practices (Munasinghe \& Malkumari, 2012:168). Carroll (1979:500) describes CSR as the economic, legal, ethical and discretionary expectations that society has of businesses at a given point in time. However, Wood and Jones (1995) asserted that stakeholders are central in this aspect since they are the source of society's expectations about CSR; they experience the business's behaviour and they evaluate the business's social performance by comparing their experiences with their prior expectations. Hence, CSR can be equated with the notions of giving back to the community, treating employees fairly and offering quality products and services. The common CSR activities include sponsorship programmes, the provision of career development and training to employees, waste recycling, and participation in community activities (Suprawan, De Bussy 
\& Dickinson, 2009:4). Like their larger counterparts, SMEs cannot operate their businesses without employees, customers and community support. It is argued that SMEs act responsibly because their legitimacy with immediate stakeholders is at stake (Jamali, Zanhour \& Keshishian, 2009:357). Carroll (1999) suggests that SMEs could implement CSR policies successfully and this would directly affect their competitiveness. SMEs have stakeholder relationships that are similar to (Jenkins, 2006a) and stronger than (Perrini, 2006) those of large companies. This implies that SMEs have stakeholders in the common range with large companies and the purpose of stakeholder management is similar, their main concern being to reduce their risk by managing stakeholders (Jenkins, 2006a). Furthermore, SMEs are closer to stakeholders like community and their employees (Perrini, 2006).

In line with the existing literature (Vaaland, Heide \& Gronhaug, 2008), CSR is viewed as being implemented through stakeholder theory, where the main stakeholders include the environment, the community, customers and employees. CSR involves working in partnership with local communities, making socially sensitive investments, developing relationships with employees, customers and their families, and involvement in activities that promote environmental conservation and sustainability (Maimunah, 2009:2). Based on previous research (Kramer, Pfitzer \& Lee, 2005:24; Mandl \& Dorr, 2007:16; UNIDO, 2008:3 and Szabo 2008:21) and for the purposes of this study, some categories of CSR factors, which also apply to SMEs, have been taken to include workforce-oriented CSR factors, society-oriented CSR factors, market-oriented CSR factors, and environmentally oriented CSR factors. These factors can individually or collectively lead to the increased competitiveness of SMEs in the long term in terms of increased sales volume, growth rate, market share and profitability (Jamaludin \& Hasun, 2007:6; Mandl \& Dorr, 2007:49; Salavou \& Avlonitis, 2008:976). The proposed hypothesised model, illustrated in Figure 1, illustrates the relationships between the selected CSR factors as independent variables and increased competitiveness as the dependent variable.

Figure 1

CSR factors influencing the increased competitiveness of SMEs Independent variables Dependent variable

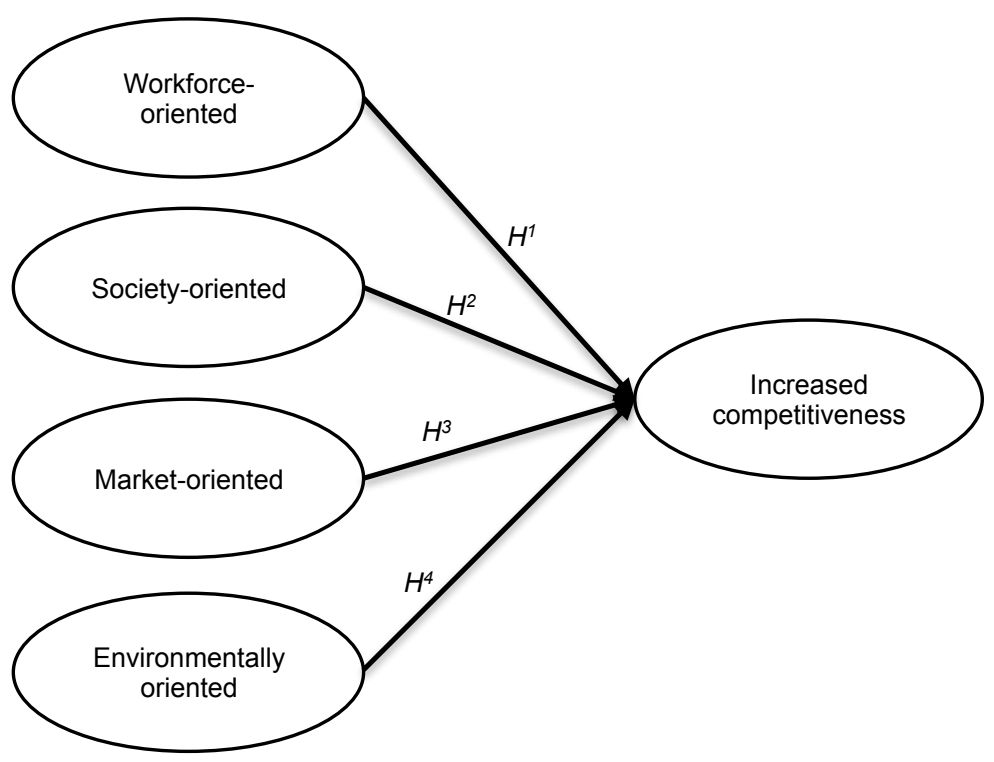


In Figure 1 (the hypothesised model), the CSR factors (Workforce-oriented, Society-oriented, Market-oriented and Environmentally oriented CSR activities) impact on Increased competitiveness (the dependent variable), which could be measured by profitability, market share, sales volume and growth rate.

\subsection{Independent variables}

In this study, the independent variables comprise CSR factors which are discussed in the subsequent subsections.

\subsubsection{Workforce-oriented CSR activities}

In this study, the factor Workforce-oriented CSR activities refers to those activities aimed at improving the working conditions of workers by offering training and staff development, creating equal opportunities and diversity, and helping workers to maintain a work-life balance. According to Fiori, Di Donato and Izzo (2007:8), the measures of workforce-oriented CSR activities are based on health and safety systems, systems for employee training and development, equal opportunities policies, systems for good employee relations, and systems for job creation and security. Accordingly, motivation and retention of employees are a key driver and a main focus area of CSR initiatives within SMEs (Jenkins, 2009:23).

In a survey of European SMEs (Mandl \& Dorr, 2007:41), between 86 per cent and 95 per cent of Austrian businesses revealed that being a role model for employees by providing equal treatment to employees, a fair salary structure and honest contracts is an important workforce-oriented CSR function. A survey of Danish SMEs (European Commission, 2005a:11) demonstrates that the businesses that implemented workforce-related CSR activities experienced a positive financial impact. Apart from the direct financial impact, businesses indicated that workforce-oriented CSR activities have a positive impact in relation to their reputation and ability to attract and retain employees. This outcome of CSR activities has a positive influence on the long-term competitiveness of SMEs.

Furthermore, a survey of Malaysian SMEs (Jamaludin \& Hasun, 2007:12) indicates that staff training is one of the most important investments made by businesses to increase the value of their human capital. Skilled employees are likely to be more efficient in carrying out their duties, which results in high quality output and waste reduction. This will directly increase business sales, market share, profit, and growth. Thus, a highly skilled and trained workforce is a key resource in effective competitiveness since employees' knowledge and experience are unique intangible business assets (Brdulak, 2006:7). Similarly, the findings of a UK-wide study of socially responsible SMEs revealed that businesses which improved the work-life balance of employees or provided excellent training and development opportunities gained a competitive advantage in terms of increased market share (Jenkins, 2009:28). Based on this anecdotal and empirical evidence, the following relationship is hypothesised:

$H^{l}$ : There is a positive relationship between the existence of workforce-oriented CSR activities and increased competitiveness of SMEs.

\subsubsection{Society-oriented CSR activities}

For the purposes of this study, the factor Society-oriented CSR activities refer to those activities aimed at community, sports, health and well-being, education, assistance to low income groups and community participation. Such activities are viewed as support for social and cultural community activities, as well as community development and other related issues (Vives, 2006:46). Support for sporting activities is the preferred activity among SMEs in nearly all the countries in Europe (European Commission, 2002:13). Similarly, SMEs appear to be to most active in supporting sporting, health and cultural activities in Latin America (Vives, 2006:46). Research conducted by Polášek (2010:140) emphasised the following societyoriented CSR activities as important to SMEs, namely: financial and in-kind (material) donations; volunteerism; education of the public; support of various kinds for the local quality of life (e.g. sports, culture, etc) and collaboration with local schools, authorities and various organisations.

Businesses depend on the health, stability and prosperity of the communities in which they operate. The reputation of a business at its location-its image as an employer and producer, but also as an actor on the local 
scene, certainly influences its competitiveness (Polášek, 2010:56). It is further reported that a business which is considered socially responsible can benefit from its enhanced reputation within the public and business community, thereby increasing its ability to attract capital and improve its competitiveness (Schiebel \& Pöchtrager, 2003:119). Against this background, the following is hypothesised:

$H^{2}$ : There is a positive relationship between the existence of society-oriented CSR activities and increased competitiveness of SMEs.

\subsubsection{Market-oriented CSR activities}

In this study, the factor Market-oriented CSR activities refers to the way in which a business focuses on the needs of its customers by responding quickly to consumers' orders and complaints about its products and services, is open at convenient times, provides customers with useful information, treats customers fairly, charges fair prices, and generates profit without cheating the customers. According to the European Commission (2011:5), marketoriented CSR activities include targeting improvements in product quality and safety, providing voluntary customer services, charging fair prices, ethical marketing, timely payments, cooperation with local partners, promoting good standards in supply chains, and supporting the creation of local/regional business cooperatives. A socially responsible business is expected to conduct its activities in a transparent manner and to have positive relationships with its customers. A business's ability to succeed in the long term depends on its ability to create lasting and high quality sales networks for its products (Polášek, 2010:138).

According to a survey conducted among Danish SMEs, important market-oriented CSR activities include general ethical business practices, responsible customer relations, product responsibility and the involvement of customers in important decisions on the business's product (European Commission, 2005a:42). Similarly, a survey of Danish SMEs indicated that market-oriented CSR activities had a positive impact on the financial performance of a business (European Commission, 2005b:6). A survey among Czech SMEs (Polášek, 2010: 138) revealed that they stood out among competitors as a result of the benefits derived from implementing market-oriented CSR activities.

Market-oriented CSR activities could help businesses to attract and retain customers, which in turn ensures the long-term survival of the business. Ali, Rehman, Yilmaz, Nazir and Ali (2010:477) confirm that businesses with sound market-oriented CSR activities enjoy increased customer loyalty, which in turn influences their competitiveness. Hence, a business is considered competitive if it can produce products or services of superior quality or at a lower cost than its competitors (European Competitiveness Report, 2008:106). Based on this discussion, the following is hypothesised:

$H^{3}$ : There is a positive relationship between the existence of market-oriented CSR activities and increased competitiveness of SMEs.

\subsubsection{Environmentally oriented CSR activities}

In this study, the factor Environmentally oriented CSR activities refers to the measures a business can take to minimise its negative impact on the natural environment, such as the ecological and economic use of natural resources, using environmentally friendly packaging, recycling, waste reduction, energy and water conservation, and pollution control. According to the European Commission (2005b:33), the most important environmentally oriented CSR activities concern the consumption of materials and energy, and the handling of pollution and waste in the most environmentally friendly manner. A survey of European SMEs revealed that environmentally oriented CSR activities are generally aimed at designing environmentally friendly products or production processes or being actively engaged in recycling activities (Mandl \& Dorr, 2007:47).

Danish SMEs revealed that environmentally oriented CSR activities had a positive impact on their business reputation, which in turn influenced their competitiveness (European Commission, 2005b:35). A survey of local SMME owners/managers in the Nelson Mandela Bay region in South Africa revealed a positive relationship between embracing environmentally oriented CSR activities and increased competitiveness in terms of profitability (Viviers, 2009:48). Customers find it desirable to 
associate themselves with businesses and products that are eco-friendly. Hence, businesses that are environmental stewards stand to gain many satisfied and loyal customers (Yazdanifard \& Mercy, 2011:1). This in turn may influence business performance. Based on anecdotal and empirical evidence from the above, the following relationship is hypothesised:

$H^{4}$ : There is a positive relationship between the existence of environmentally oriented CSR activities and increased competitiveness of SMEs.

\section{5}

\section{Dependent variable}

Competitiveness can be treated as a dependent, independent, or intermediary variable, depending on the perspectives from which the subject is approached. Such levels and approaches truly reflect the wide applications of this concept (Man, Lau \& Chan, 2002:125). In this study, Increased competitiveness is treated as a dependent variable, and it refers to a business's ability to sustain its long-term performance better than its competitors in the market, as indicated by profitability, market share, sales and growth rate.

The literature connecting CSR factors and competitiveness is limited, and most of the existing studies define competitiveness in terms of financial performance or productivity (Olsson, 2011:20). However, there are many indicators of competitiveness, depending on the nature of the study, the industry and the size of the business. For instance, in a study of founder-managed natural food stores in the USA, the researchers measured business performance using net worth, profitability, sales revenue, market share and sales volume (Segal, Borgia \& Schoenfeld, 2010:76). Similarly, Mandl and Dorr (2007:49) found that the competitive advantage indirectly caused by the CSR activities of SMEs leads to a higher level of competitiveness, as indicated by increased sales volume, market share and profitability.

A survey of independent Greek SMEs also measured business competitiveness using profitability, sales growth, sales volume and market share as indicators of business success
(Salavou \& Avlonitis, 2008:976). Similarly, Jamaludin and Hasun (2007:6) measured competitiveness of the business by comparing the actual performance of the business sales, market share, profit, growth, demand and customer loyalty with the forecast. The survey of five owner-managers of SMEs established that most SMEs follow a hybrid approach to measuring competitiveness because of their concerns about meeting both the financial and the non-financial returns. Financial measures include profits and sales turnover whereas nonfinancial measures are the long-term growth rate and market share of the business (Chong, 2008:7). Against this background, it can be concluded that most SMEs use profitability, market share, sales and growth rate as measures of competitiveness.

\section{6}

\section{Methodology}

This section explains the research design and methodology that were utilised to address the primary objective of this study.

\subsection{Scale development}

In this study, the factors under investigation were operationalised using reliable and valid items sourced from measuring instruments validated in previous empirical studies, as indicated in Table 1 below. However, where sufficient items were not available, additional questions were self-generated based on an intensive analysis of secondary sources to ensure that every variable in the measuring instrument was represented by adequate items. Where necessary, the items were rephrased to make them more relevant to the present study. The measuring instrument consisted of two sections. Section A consisted of 60 statements (items) related to CSR factors that influence SMEs' competitiveness, using a seven-point Likert-type interval scale $(1=$ strongly disagree and $7=$ strongly agree). Section $\mathrm{B}$ of the questionnaire sought demographic information relating to both the respondents and the SMEs in which they operate and consists of seven variables using a nominal scale. 
Table 1

Sources of previously validated items used in the measuring instrument

\begin{tabular}{|l|l|}
\hline \multicolumn{1}{|c|}{ Factors } & \multicolumn{1}{c|}{ References } \\
\hline Workforce-oriented CSR activities & $\begin{array}{l}\text { DeVaney and Chen (2003), Eybers (2010:171), Herpen, Meulenberg and Pennings } \\
\text { (2003:19), Polášek (2010:100) and Somyot (2008:121) }\end{array}$ \\
\hline Society-oriented CSR activities & $\begin{array}{l}\text { Herpen et al., (2003:19), Szlávik, Pálvölgyi, Csigéné Nagypál and Füle (2006:21), } \\
\text { Timo (2006:101), and Vives (2006:51) }\end{array}$ \\
\hline Market-oriented CSR activities & $\begin{array}{l}\text { Herpen et al., (2003:19), Heyder and Theuvsen (2009), Maignan and Ferrell, } \\
(2004), \text { and Somyot (2008:121) }\end{array}$ \\
\hline $\begin{array}{l}\text { Environmentally oriented CSR } \\
\text { activities }\end{array}$ & $\begin{array}{l}\text { Herpen et al., (2003:19), Maignan and Ferrell, (2004), Núñez (2008: 64), and Timo } \\
\text { (2006:101) }\end{array}$ \\
\hline Increased competitiveness & $\begin{array}{l}\text { Depperu and Cerrato (2005:10), Konstantinidis, (2009:2), Salavou and Avlonitis, } \\
\text { (2008:976), Chew, Yan, and Cheah (2008:210) }\end{array}$ \\
\hline
\end{tabular}

\subsection{Sampling and data collection}

A non-probability sampling technique, namely purposive sampling, and specifically judgmental sampling, was used to select respondents from different industrial sectors in the Kampala District in Uganda, whose workforce ranged from 5 to 100 employees. These data were obtained from the Business Register Update of the Uganda Bureau of Statistics (UBOS 2007), which covered all the sectors of the Ugandan economy except the public sector and provided an updated list of businesses employing up to 5 but not more than 100 persons. In this study, SMEs are considered to be businesses that employ more than 5 but fewer than 100 persons.

\subsection{Data analysis}

The data obtained from the 383 usable questionnaires were subjected to different statistical analyses. An Analysis of Variance (ANOVA) was undertaken to determine the influence of demographic variables with a nominal scale on the dependent variables. An exploratory factor analysis was carried out, and Cronbach's alpha coefficients were calculated to determine the discriminant validity and reliability of the measuring instrument. The correlations were assessed using Structural Equation Modelling (SEM). Besides determining the validity of the measurements, the objective of doing factor analysis in this study was to identify representative variables and to create new variables, if any, to be used in the subsequent analysis. The idea was to obtain the most parsimonious set of variables for inclusion in the analysis. The software programme SPSS
18 for Windows was used for this analysis.

\section{7}

\section{Discussion of results}

The sections below present the results of the study.

\subsection{Demographic profile of respondents}

The study considered the total population of 1 069848 SMEs in Uganda (Hatega, 2007:3; Uganda Ministry of Finance, Planning and Economic Development July, 2011). A structured, self-administered questionnaire was distributed to 750 potential SME respondents. A total of 383 usable questionnaires were received from respondents, resulting in a response rate of 51 per cent.

The vast majority of respondents were males (63 per cent), and had been operating between three and five years (72 per cent). Most respondents (85 per cent) were employed as managers (CEOs or functional managers) in areas such as finance or marketing, and had attained a national certificate or diploma (60 per cent). The vast majority (67 per cent) were operating private limited companies, employing between 11 and 20 full-time employees (40 per cent). The majority of the respondents ( 49 per cent) were unwilling to disclose information regarding their annual turnover. Of those who were willing to disclose information, 26 per cent indicated that they generated less than UGX 50 million (ZAR 161 290) per annum. Summaries of sample descriptions are presented in Table 2 below. 
Table 2

Demographical profile of respondents

\begin{tabular}{|c|c|c|c|}
\hline & \multirow{3}{*}{$\begin{array}{c}\text { Frequency } \\
243\end{array}$} & \multirow{3}{*}{$\begin{array}{c}\text { Percentage } \\
63 \%\end{array}$} \\
\hline & & & \\
\hline COndlor mone & Male & & \\
\hline Genaer of responaent & Female & 140 & $37 \%$ \\
\hline \multirow{5}{*}{$\begin{array}{l}\text { Number of years in business by } \\
\text { respondent }\end{array}$} & Less than three years & 0 & 0 \\
\hline & Between 3 and 5 years & 273 & $72 \%$ \\
\hline & Between 6 and 10 years & 86 & $23 \%$ \\
\hline & More than 10 years & 23 & $6 \%$ \\
\hline & Missing system & 1 & \\
\hline \multirow{3}{*}{$\begin{array}{l}\text { Respondent's position or title in } \\
\text { business }\end{array}$} & Owner (silent partner) & 25 & $7 \%$ \\
\hline & Owner and active manager in the business & 33 & $9 \%$ \\
\hline & Employed manager (CEO or functional manager) & 325 & $85 \%$ \\
\hline \multirow{6}{*}{ Level of education of respondent } & Ordinary level certificate & 3 & $.8 \%$ \\
\hline & Advanced level certificate & 12 & $3 \%$ \\
\hline & National certificate or diploma & 229 & $60 \%$ \\
\hline & Bachelor's degree & 127 & $33 \%$ \\
\hline & Master's degree and higher & 11 & $3 \%$ \\
\hline & Other & 1 & $.3 \%$ \\
\hline \multirow{6}{*}{ Form of enterprise } & Sole trader & 53 & $14 \%$ \\
\hline & Partnership & 59 & $15 \%$ \\
\hline & Private limited company & 256 & $67 \%$ \\
\hline & Trust & 12 & $3 \%$ \\
\hline & Other & 2 & $.5 \%$ \\
\hline & Missing system & 1 & \\
\hline \multirow{8}{*}{ Branch/sector } & Manufacturing/processing & 82 & $21 \%$ \\
\hline & Business services & 76 & $20 \%$ \\
\hline & Trade (retailing/wholesaling) & 41 & $11 \%$ \\
\hline & Hotels and restaurants & 75 & $20 \%$ \\
\hline & Finance & 20 & $5 \%$ \\
\hline & Insurance & 6 & $2 \%$ \\
\hline & Education & 62 & $16 \%$ \\
\hline & Health and social work & 21 & $6 \%$ \\
\hline \multirow{6}{*}{$\begin{array}{l}\text { Size of the business (Number of } \\
\text { full-time employees) }\end{array}$} & Less than 5 & 3 & $8 \%$ \\
\hline & Between 5 and 10 & 129 & $34 \%$ \\
\hline & Between 11 and 20 & 150 & $40 \%$ \\
\hline & Between 21 and 50 & 73 & $19 \%$ \\
\hline & More than 50 & 24 & $6 \%$ \\
\hline & Missing system & 4 & \\
\hline \multirow{6}{*}{$\begin{array}{l}\text { Size of the business (range of } \\
\text { annual turnover) }\end{array}$} & Less than UGX 50 million per annum & 100 & $26 \%$ \\
\hline & UGX 51-100 million per annum & 61 & $16 \%$ \\
\hline & UGX 101-200 million per annum & 19 & $5 \%$ \\
\hline & More than UGX 200 million per annum & 14 & $4 \%$ \\
\hline & Not willing to disclose & 187 & $49 \%$ \\
\hline & Missing system & 2 & \\
\hline
\end{tabular}

Note: $Z A R 1=$ UGX 310 


\subsection{Discriminant validity and reliability results}

All items in the questionnaire were subjected to exploratory factor analysis to determine the discriminant validity among the variables, using the software programme SPSS 18 for Windows. Based on the relational nature of the variables, principal axis factoring with an oblique (oblimin with Kaiser normalisation) was specified as the extraction and rotation method for submodels. While ascertaining the constructs to extract, the percentages of variance explained and the individual factor loadings were taken into account.

In this study, Principal Component Analysis with Kaiser-Meyer-Okin Rotation was specified as the extraction and rotation method. Bartlett's Test of Sphericity reported a KMO of 0.810 $(\mathrm{p}<0.001)$, which confirmed that the data were factor-analysable. The exploratory factor analysis was unable to confirm all the latent variables as originally anticipated. Of all the items intended to measure CSR factors, only items measuring market-oriented CSR activities and workforce-oriented CSR activities loaded as expected. However, the items measuring environmentally oriented CSR activities loaded onto two separate factors which were renamed Environmentally oriented CSR activities and Regulated CSR activities. Furthermore, one of the items originally expected to measure the construct Society-oriented CSR activities loaded onto environmentally oriented CSR activities, leaving three items which loaded together onto the Society-oriented CSR activities factor.

While conducting factor analysis, two items (ECA5 and ECA4) that were originally expected to load onto the construct Environmentally oriented CSR activities loaded together onto a separate construct that was named Regulated CSR activities. A business which takes the government regulations about the environment beyond what the law requires is more likely to gain a competitive advantage. Businesses may strategically commit to modest environmental improvements that constrain regulators' ability to set tough standards (Lyon \& Maxwell, 2008:248). Accordingly, an additional hypothesis was formulated (see Table 4) to test this relationship.

Factor loadings of 0.30 and 0.40 are considered significant for sample sizes of 200 and 350 respectively (Hair, Black, Babin, Anderson \& Tatham, 2006:128). In this study, factor loadings of $\geq 0.4$ were reported for all items. Accordingly, Cronbach's alpha coefficients greater than 0.70 (Nunnally \& Bernstein 1994; Suhr \& Shay, 2009:3) were obtained for all constructs, confirming the reliability of measuring scales. Table 3 presents a summary of operational definitions of the factors and the details pertaining to the validity and reliability of the measuring instrument.

Table 3

Measurement instrument analyses

\begin{tabular}{|c|c|c|c|}
\hline Operationalisation of factors & Items & Factor loadings & $\begin{array}{l}\text { Cronbach's } \\
\text { alpha }\end{array}$ \\
\hline $\begin{array}{l}\text { Market-oriented CSR activities refer to the way in which a business } \\
\text { focuses on the needs of its customers by responding quickly to } \\
\text { consumers' orders and complaints about its products and services, } \\
\text { whether it is open at convenient times, whether it treats customers fairly, } \\
\text { and whether it charges fair prices and makes a profit without cheating } \\
\text { customers. }\end{array}$ & 7 & $\begin{array}{l}\text { Max: } 0.699 \\
\text { Min: } 0.607\end{array}$ & 0.800 \\
\hline $\begin{array}{l}\text { Environmentally oriented CSR activities refer to the business's } \\
\text { involvement in supporting environmental awareness programmes and } \\
\text { sponsoring sporting and cultural events as well as striving to reduce } \\
\text { waste. }\end{array}$ & 3 & $\begin{array}{l}\text { Max: } 0.868 \\
\text { Min: } 0.770\end{array}$ & 0.804 \\
\hline $\begin{array}{l}\text { Regulated CSR activities refer to the business's taking the government } \\
\text { regulations about the environment beyond what the law requires and } \\
\text { using packaging materials that are environmentally friendly. }\end{array}$ & 2 & $\begin{array}{l}\text { Max: } 0.852 \\
\text { Min: } 0.801\end{array}$ & 0.713 \\
\hline $\begin{array}{l}\text { Workforce-oriented CSR activities refer to the business's believing in staff } \\
\text { development for all employees and providing them with a sense of job } \\
\text { security. }\end{array}$ & 2 & $\begin{array}{l}\text { Max: } 0.850 \\
\text { Min: } 0.800\end{array}$ & 0.713 \\
\hline $\begin{array}{l}\text { Society-oriented CSR activities refer to the business's giving donations to } \\
\text { the community, assisting them with projects and sharing some of its } \\
\text { profit with the community. }\end{array}$ & 3 & $\begin{array}{l}\text { Max: } 0.716 \\
\text { Min: } 0.628\end{array}$ & 0.758 \\
\hline
\end{tabular}




\subsection{Reformulated hypotheses}

Based on the results of the exploratory factor analysis, it was considered essential to modify the original hypotheses, as summarised in Table 4 below.

Table 4

Reformulated hypotheses

\begin{tabular}{|ll|}
\hline$H^{1}:$ & $\begin{array}{l}\text { There is a positive relationship between the existence of Workforce-oriented CSR activities and Increased } \\
\text { competitiveness of SMEs. }\end{array}$ \\
\hline$H^{2}:$ & $\begin{array}{l}\text { There is a positive relationship between the existence of Society-oriented CSR activities and Increased competitiveness } \\
\text { of SMEs. }\end{array}$ \\
\hline$H^{3}:$ & $\begin{array}{l}\text { There is a positive relationship between the existence of Market-oriented CSR activities and Increased competitiveness } \\
\text { of SMEs. }\end{array}$ \\
\hline$H^{4}:$ & $\begin{array}{l}\text { There is a positive relationship between the existence of Environmentally oriented CSR activities and Increased } \\
\text { competitiveness of SMEs. }\end{array}$ \\
\hline$H^{5}:$ & There is a positive relationship between Regulated CSR activities and the Increased competitiveness of SMEs. \\
\hline
\end{tabular}

\subsection{Structural equation modelling results}

To determine the extent to which the proposed model represents an acceptable approximation of the data, various fit indices were used. These include the Satorra-Bentler scaled Chisquare $\left(\chi^{2}\right)$, the ratio of Chi-square to degrees of freedom $\left(\chi^{2} / \mathrm{df}\right)$, RMSEA, and the 90 per cent confidence interval for RMSEA (Hoe, 2008:78). The indices present proof of a model with a reasonable fit.

The empirical results of this study (see Figure 2) indicate that environmentally oriented CSR activities (hypothesis $H^{4}$ ) do not have an influence on the increased competitiveness of SMEs. Hence, hypothesis $H^{4}$ is rejected. A possible explanation for this result is that SMEs, particularly in developing countries, lack the experience and financial resources to integrate environmental aspects into their operations in order to enhance their competitiveness. However, workforce-oriented CSR activities, society-oriented CSR activities, market-oriented CSR activities and regulated $C S R$ activities positively influence the increased competitiveness of SMEs. Support is thus found for hypotheses $H^{l}, H^{2}, H^{3}$ and $H^{5}$.

Figure 2 below demonstrates that the independent variables Workforce-oriented CSR activities (0.36), Society-oriented CSR activities (0.16), Market-oriented CSR activities (0.56) and Regulated CSR activities (0.12) significantly influence the dependent variable. These relationships proved significant as the $\mathrm{p}$-values for their path coefficients were slightly exceeded by the critical values of 1.96 $(\mathrm{p}<0.05)$ and/or $3.30(\mathrm{p}<0.001)$.

It can be seen from Figure 2 that a positive relationship (path coefficient $=0.36 ; \mathrm{p}<$ 0.000) exists between Workforce-oriented CSR activities and Increased competitiveness (Hypothesis $H^{l}$ ) of SMEs. This implies that businesses which meet employee expectations such as job security, training and development are likely to be more competitive than those that ignore the plight of their employees. The findings of this study are in line with a survey of Danish SMEs (European Commission, 2005a:11), which showed that the businesses which had implemented workforce-related CSR activities experienced a positive financial impact, and that such activities have a positive influence on the long-term competitiveness of the SMEs. Furthermore, a survey of Romanian SMEs (European Commission, 2007:21) revealed that businesses which exhibited constant concern for employee training experienced an increase in their profits.

The current study has revealed a positive relationship between Society-oriented CSR activities and Increased competitiveness (path coefficient $=0.16 ; \mathrm{p}<0.000)$ of SMEs (Hypothesis $H^{2}$ ). In other words, the more a business engages in local community activities, the more likely it is to enhance its competitiveness in the future. The findings of this study are supported by Polášek's study (2010:140) in which a significant positive relationship between society-oriented CSR activities and increased competitiveness was reported. Furthermore, a business which invests in socially deprived communities will make its presence felt, 
thereby enhancing its competitiveness (Steinerová \& Makovski, 2008:6). In addition, a survey of Romanian SMEs (European Commission, 2007: 17) revealed that businesses which supported local community projects realised better sales and financial results. Hence, a business that voluntarily participates in local community activities, such as making donations to the community, assisting them with projects and sharing some of its profits with the community, is more likely to gain a competitive advantage in the long term.

Figure 2

Empirical findings of CSR factors influencing the increased competitiveness of SMEs

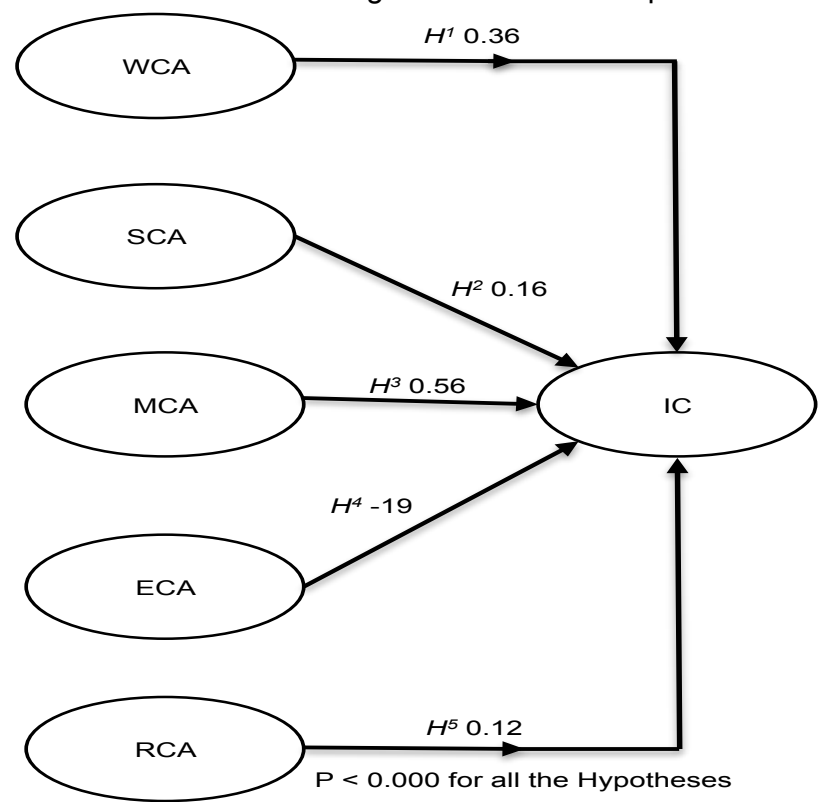

Key: WCA (Workforce-oriented CSR activities), SCA (Society-oriented CSR activities), MCA (Market-oriented CSR activities), ECA (Environmentally oriented CSR activities), RCA (Regulated CSR activities), IC (Increased competitiveness)

A significant positive relationship emerged between Market-oriented CSR activities and Increased competitiveness, as a path coefficient of $0.56(p<0.000)$ was reported. This implies that the more a business adopts marketoriented CSR activities, such as treating customers fairly and responding quickly to their orders and complaints about its products and services, the more likely it is to enhance its competitiveness in the long run. Consequently, hypothesis $H^{3}$ is accepted, as satisfactory evidence has been found to support the relationship. This empirical relationship is supported by previous research (e.g. European Commission, 2005a:6), which reported that market-oriented CSR activities had a positive impact on the sales growth, market share and profitability of a business. Furthermore, treating customers with respect has a direct positive effect on the business's profits (Uddin, Hassan \& Tarique,
2008:205). To remain competitive, a business must be willing to satisfy the desires and needs of its customers because they are its foundation.

The results of this study show a significant positive relationship between Regulated CSR activities and Increased competitiveness (path coefficient $=0.0 .12 ; \mathrm{p}<0.000)$ of SMEs (Hypothesis $H^{5}$ ). This finding implies that if a business takes the government regulations about the environment beyond what the law requires and uses packaging materials that are environmentally friendly, it is more likely to gain and sustain a competitive advantage in the future. An environmental attitudes survey carried out with 60 SMEs in East Anglia found that willingness to become involved in environmental initiatives is associated with better opportunities for SMEs to become more competitive (Peters \& Turner, 2003:3). 
8

\section{Conclusions and recommendations}

The findings of this study confirm positive relationships between all the CSR factors (Workforce-oriented CSR activities, Societyoriented CSR activities, Market-oriented CSR activities and Regulated CSR activities) and the Increased competitiveness of SMEs. However, the results reveal a negative relationship between environmentally oriented CSR activities and Increased competitiveness.

A significant positive relationship between Workforce-oriented CSR activities and Increased competitiveness of SMEs was reported. This result suggests that a business which believes in staff development and gives its staff a sense of job security is more likely to enhance its competitiveness in the long run. SMEs are encouraged to continuously improve the skills of their employees through training and retraining, provide a safe and conducive working environment, responsible and fair remuneration, and offer their workforce flexible working hours. This will provide their employees with greater motivation and a sense of job security, thereby gaining and retaining a competitive advantage.

The findings of the study show that societyoriented CSR activities have a significant positive influence on increased competitiveness of SMEs. This means that a business which voluntarily participates in local community activities, such as providing the community with donations, assisting them with projects and sharing some of its profit with the community, is more likely to become competitive in the long run. SMEs should take an interest in the overall well-being of the community by engaging in local community activities such as giving the community donations of necessary funds and goods, awarding grants to children for outstanding scholastic performance, and assisting the community with general development projects (e.g., health care and sports) in order to build good community relations and thereby enhance their competitiveness.

The findings of this study confirm that market-oriented CSR activities have a significant positive influence on increased competitiveness of SMEs. If a business concentrates on the needs of its customers by responding quickly to their orders and complaints, staying open at convenient times and treating its customers fairly, it is more likely to improve its competitiveness. Hence, SMEs should provide customised services, establish procedures for meeting the needs of customers and conduct customer surveys to ensure that customers have appropriate opportunities to provide feedback and complaints to the business, avoid discriminatory policies in certain markets, and deliver quality products/services which offer good value for money. These actions can help SMEs to establish good relationships with customers, thereby enhancing their competitiveness in the long term.

The results of this study show a significant positive relationship between regulated CSR activities and increased competitiveness of SMEs. This implies that if a business takes the government regulations about the environment beyond what the law requires and uses packaging materials that are environmentally friendly, it is more likely to be well known among its stakeholders and become competitive in the long run. Hence, SMEs should consult with government on the CSR initiatives that are most beneficial to important stakeholders and the business. SMEs should also focus on the use of environmentally friendly packing materials that are costeffective in order to improve their image and enhance their competitiveness.

\section{9}

\section{Limitations}

In empirical studies, it is important to identify and consider limitations when arriving at interpretations and conclusions. This study is purely quantitative in nature, yet a triangulation (a combination of quantitative and qualitative approaches) in data collection could have made for a deeper understanding of the phenomenon studied, and enhanced the accuracy and validity measures. Another limitation is that the proposed hypothesised model focuses on a few selected CSR factors. Future studies could investigate various other CSR factors such as economic and ethical CSR factors and incorporate them into a more comprehensive model for investigating the influence of CSR factors on the competitiveness of SMEs. 
Although a few limitations have been identified, the present study has contributed to the empirical body of research on SMEs. The study also provides an important first step in gaining insights into specific CSR factors that influence the competitiveness of SMEs.

\section{References}

ALI, I., REHMAN, K.U., YILMAZ, K.U., A.K., NAZIR, S. \& ALI, J.F. 2010. Effects of corporate social responsibility on consumer retention in cellular industry of Pakistan. African Journal of Business Management, 4(4):475-485.

BRDULAK, A. 2006. CSR as a way of competition between corporations: CSRM - Corporate social responsibility and sustainable management. Available at: http://www.feem.it/Feem/Pub/Publications/ CSRPapers [accessed 2006-01-15].

CARROLL, A.B. 1979. A three-dimensional conceptual model of corporate performance. Academy of Management Review, 4(4):497-505.

CARROLL, A.B. 1999. Corporate social responsibility: Evolution of a definitional construct. Business \& Society, 38(3):268-96.

CHARITOUDI, G., SARIANNIDIS, N. \& GIANNARAKIS, G. 2011. The development guide for corporate social responsibility programming. European Journal of Scientific Research, 65(1):20-27.

CHEW, D.A.S., YAN, S. \& CHEAH, C.Y.J. 2008. Core capability and competitive strategy for construction of SMEs in China. Chinese Management Studies, 2(3):203-214.

CHONG, H.G. 2008. Measuring performance of small-and-medium sized enterprises: The grounded theory approach. Journal of Business and Public Affairs, 2(1):1-13.

DEPPERU, D. \& CERRATO, D. 2005. Analyzing international competitiveness at the firm level: Concepts and measures, Working Paper No. 32, Dipartimento Scienze Sociali - Sezione Economia Aziendale, Universita Cattolica del Sacro Cuore, Piacenza.

DEVANEY, S.A. \& CHEN, Z.S. 2003. Job satisfaction of recent graduates infinancial services, US Department of Labour. Bureau of Labour Statistics, Compensation and Working Conditions Online. Purdue University, USA.

EUROPEAN COMMISSION. 2002. Communication from the Commission concerning Corporate Social Responsibility: A business contribution to sustainable development, COM (2002) No. 347. Official publications of the European Commission, Brussels.

EUROPEAN COMMISSION. 2005a. The new SME definition. User guide and model declaration. European. 1 January 2005.

EUROPEAN COMMISSION. 2005b. Enterprise and innovation in deprived urban areas: Sharing the European experience. The European Learning Network Policy Bulletin Issue 3 - July 2005.

EUROPEAN COMMISSION. 2007. Opportunity and responsibility. How to help more small businesses to integrate social and environmental issues into what they do. Report, Brussels.

EUROPEAN COMMISSION. 2011. Corporate sustainability information and training in Europe: Situation analysis on corporate social responsibility (CSR) activities on SMEs. Poland.

EUROPEAN COMPETITIVENESS REPORT 2008. Overview of the links between corporate social responsibility and competitiveness. Available at: http://ec.europa.eu/enterprise/policies/sustainablebusiness/ files/csr/documents/csrreportv002_en.pdf [accessed 2010-06-20].

EYBERS, C. 2010. Copreneurships in South African small and medium-sized family businesses. Unpublished doctoral thesis, Nelson Mandela Metropolitan University.

FILHO, J.M.D., WANDERLEY, L.S.A., GÓMEZ, C.P. \& FARACHE, F. 2010. Strategic corporate social responsibility management for competitive advantage. Brazilian Administration Review, 7(3):294-309.

FIORI, G., DI DONATO, F. \& IZZO, M.F. 2007. Corporate social responsibility and firm's performance: An analysis on Italian listed companies. Luiss University, Italy.

HAIR, J.F., BLACK, W.C., BABIN, J.B., ANDERSON, R.E. \& TATHAM, R.L. 2006. Multivariate data analysis. $\left(6^{\text {th }}\right.$ ed.) Upper Saddle River, N.J.: Pearson/Prentice Hall.

HATEGA, G. 2007. SME development in Uganda. Private Sector Foundation Uganda. Paper presented at a Local SMEs Conference on 14 March, 2007, Sheraton Kampala. 
HERPEN E., MEULENBERG M. \& PENNINGS J. 2003. Consumers' evaluations of socially responsible activities in retailing. Mansholt Working Paper, Mansholt Graduate School of Social Sciences, Wageningen University.

HEYDER, M. \& THEUVSEN, L. 2009. Corporate social responsibility in agribusiness: Empirical findings from Germany. European Association of Agricultural Economists, $113^{\text {th }}$ Seminar, Chania, Crete, Greece. HOE, S.L. 2008. Issues and procedures in adopting structural equation modeling technique. Journal of Applied Quantitative Methods, 3(1):76-83.

JAMALI, D., ZANHOUR, M. \& KESHISHIAN, T. 2009. Peculiar strengths and relational attributes of SMEs in the context of CSR. Journal of Business Ethics, 87:355-377.

JAMALUDIN, Z. \& HASUN, F.M. 2007. The importance of staff training to the SMEs' performance. Paper presented at the International Colloquium on Business and Management (ICBM), Bangkok Palace Hotel, Bangkok, Thailand.

JENKINS, H. 2006a. Make a difference where you can: Corporate social responsibility in UK SMEs. The ESRC Centre for Business Relationships, Accountability, Sustainability and Society (BRASS), Cardiff University.

JENKINS, H. 2006b. Small business champions for corporate social responsibility. Journal of Business Ethics, 67(3):241-256.

JENKINS, H. 2009. A business opportunity model of corporate social responsibility for small and mediumsized enterprises, Business Ethics: A European Review, 18(1):21-36.

KONSTANTINIDIS, C. 2009. The competitiveness of the Greek meat processing enterprises. Paper presented at the $113^{\text {th }}$ EAAE Seminar, Chania, Crete, Greece.

KRAMER, M., PFITZER, M. \& LEE, P. 2005. Competitive social responsibility: Uncovering the economic rationale for corporate social responsibility among Danish small and medium-sized enterprises. Foundation

Strategy Group and Center for Business and Government, John F. Kennedy School of Government, Harvard University.

LIU, H. \& FONG, M. 2010. The corporate social responsibility orientation of Chinese small and medium enterprises. Journal of Business Systems, Governance and Ethics, 5(3):33-50.

LYON, T.P. \& MAXWELL, J.W. 2008. Corporate social responsibility and the environment: A theoretical perspective. Review of Environmental Economics and Policy, 2(2):240-260.

MAIGNAN, I. \& FERREL, O.C. 2004. Corporate social responsibility and marketing: An integrative framework. Journal of the Academy of Marketing Science, 32(1):3-19.

MAIMUNAH, I. 2009. Corporate social responsibility and its role in community development: An international perspective. The Journal of International Social Research, 2(9).

MÁLOVICS, G. 2009. The social role and responsibility of small and medium-sized enterprises: Results of an empirical investigation applying the social capital approach. Regional Competitiveness, Innovation and Environment, JATE Press, Szeged:222-236.

MAN, T.W.Y., LAU, T. \& CHAN, K.F. 2002. The competitiveness of small and medium enterprises: A conceptualization with focus on entrepreneurial competencies. Journal of Business Venturing, 17(2):123-142. MANDL, I. \& DORR, A. 2007. CSR and competitiveness. European SMEs' good practice. Consolidated European Report, Vienna.

MUNASINGHE, M.A.T.K. \& MALKUMARI, A.P. 2012. Corporate social responsibility in small and medium enterprises (SMEs) in Sri Lanka. Journal of Emerging Trends in Educational Research and Policy Studies, 3(2):168-172.

NÚÑEZ, G. 2008. Promoting corporate social responsibility in small and medium enterprises in the Caribbean: survey results. United Nations Publications, Washington.

NUNNALLY, J.C. \& BERNSTEIN, I.H. 1994. Psychometric theory. ( $3^{\text {rd }}$ ed.) New York: McGraw-Hill. OLANREWAJU, A.D. 2012. An assessment of the impact of corporate social responsibility on Nigerian society: The examples of banking and communication industries. Universal Journal of Marketing and Business Research, 1(1):17-43.

OLSSON, E. 2011. Small firms are not little big firms: A study of corporate social responsibility in Swedish small and medium-sized enterprises. Unpublished master's thesis, Lund University Center for Sustainability Studies, Sweden. 
ORLITZKY, M., SIEGEL, D.S. \& WALDMAN, D.A. 2011. Strategic corporate social responsibility and environmental sustainability. Business \& Society, 50(1):6-27.

PERRINI, F. 2006. SMEs and CSR theory: Evidence and implications from an Italian perspective. Journal of Business Ethics, 67(3):305-316.

PETERS, M. \& TURNER, R.K. 2003. SME environmental attitudes and participation in local-scale voluntary initiatives: Some practical applications. Centre for Social and Economic Research on the Global Environment, University of East Anglia, Norwich, U.K.

POLÁŠEK, D. 2010. Corporate social responsibility in small and medium-sized companies in the Czech Republic. Unpublished doctoral thesis, Czech Management Institute, Praha.

PORTER, M.E. \& KRAMER, M. 2006. Strategy and society: The link between competitive advantage and corporate social responsibility. Harvard Business Review, 84(12):78-92.

SALAVOU, H. \& AVLONITIS, G. 2008. Product innovativeness and performance: A focus on SMEs. Management Decision, 46 (7):969-985.

SCHIEBEL, W. \& PÖCHTRAGER, D. 2003. Corporate ethics as a factor for success - the measurement instrument of the University of Agricultural Sciences (BOKU), Vienna. Supply Chain Management, 8(2):116-121.

SEGAL, G., BORGIA, D. \& SCHOENFELD, J. 2010. Founder human capital and small firm performance: An empirical study of founder-managed natural food stores. Journal of Management and Marketing Research, 4(1):71-83.

SOMYOT, W. 2008. The evaluation of service quality by socially responsible customers. Unpublished doctoral thesis, Virginia Polytechnic Institute and State University.

STEINEROVÁ, M. \& MAKOVSKI, D. 2008. Koncept CSR v praxi, průvodce odpovědným podnikáním. Available at: http://www.csronline.cz/NewsDetail.aspx?p=3\&id=581 [accessed 2001-03-28].

SUHR, D. \& SHAY, M. 2009. Guidelines for reliability, confirmatory and exploratory factor analysis. Available at: www.wuss.org/proceedings09/09WUSSProceedings/.../ANL-SuhrShay [accessed 2009-04-05]. SUPRAWAN, L., DE BUSSY, N. \& DICKINSON, S. 2009. Corporate social responsibility in the SME sector: An exploratory investigation. Curtin University of Technology, Australia.

SZABO, A. 2008. The corporate social responsibility: An opportunity for SMEs. Available at: http://www.unglobalcompact.org/http://www.unece.org/indust/sme/ResponsibleEntrepreneurship [accessed 2008-06-20].

SZLÁVIK J, PÁLVÖLGYI T, CSIGÉNÉ NAGYPÁL N \& FÜLE M. 2006. CSR in small and medium-sized companies: Evidence from a survey of the automotive supply chain in Hungary and Austria. Research paper: Rhetoric and realities: Analysing corporate social responsibility in Europe (RARE). A research project within the EU's sixth framework programme.

TIMO, C. 2006. Corporate social responsibility in Dutch SMEs: Motivations and CSR stakeholders. Unpublished doctoral thesis, Maastricht University, Maastricht.

UDDIN, M.B., HASSAN, M.R. \& TARIQUE, K.M. 2008. Three dimensional aspects of corporate social responsibility. Daffodil International University Journal of Business and Economics, 3(1):199-212.

UGANDA BUREAU OF STATISTICS (UBOS). 2007. Business register update: A report covering all the sectors of the economy except the public sector. Available at: www.ubos.org/onlinefiles/uploads/ubos/ .../20067UBRreport [accessed 2008-04-25].

UGANDA MINISTRY OF FINANCE, PLANNING AND ECONOMIC DEVELOPMENT. July, 2011. The national micro, small and medium enterprise (Msme) policy draft report.

UNIDO 2008. CSR Perceptions and activities of small and medium enterprises in seven geographical clusters. A Survey Report, Vienna, UNIDO.

VAALAND, T., HEIDE, M. \& GRONHAUG, K. 2008. Corporate social responsibility: Investigating theory and research in the marketing context. European Journal of Marketing, 42(9/10):927-53.

VIVES, A. 2006. Social and environmental responsibility in small and medium enterprises in Latin America. Journal of Corporate Citizenship, 21:39-50.

VIVIERS, S. 2009. Going green: An SMME perspective. Southern African Journal of Entrepreneurship \& Small Business Management, 2(1):30-49. 
WOOD, D.J. \& JONES, R.E. 1995. Stakeholder mismatching: A theoretical problem in empirical research on corporate social responsibility. The International Journal of Organizational Analysis, 3(3):229-267.

YAZDANIFARD, R. \& MERCY, I.E. 2011. The impact of green marketing on customer satisfaction and environmental safety. 2011 International Conference on Computer Communication and Management, IACSIT Press, Singapore. 